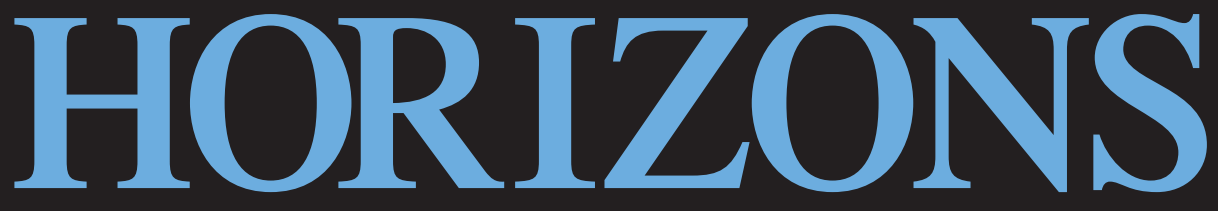

Volume 38

Fall 2011

Number 2

\title{
ARTICLES
}

Christopher Denny, "All Will Be Well”: Julian of Norwich's

Counter-Apocalyptic Revelations

Norbert J. Rigali, SJ, On Presuppositions of Theological Ethics

Kristin Colberg, The Hermeneutics of Vatican II: Reception, Authority, and Debate Over the Council's Interpretation

Erica Olson-Bang, Edward Schillebeeckx's Creation Theology as a Resource for Ecological Ethics

\section{EDITORIAL ESSAY}

Daniel K. Finn, Benedict XVI and Liberation Theology: Reason, Will, and History

THEOLOGICAL ROUNDTABLE

The Johnson Case and the Practice of Theology:

An Interim Report

Cristina L. H. Traina, Francis Schüssler Fiorenza,

Robert Masson, Richard R. Gaillardetz

REPORT OF THE COLLEGE THEOLOGY SOCIETY

Plus Reviews of 28 Books

THE JOURNAL OF THE COLLEGE THEOLOGY SOCIETY

PUBLISHED AT VILLANOVA UNIVERSITY 


\title{
HORIZONS
}

\section{The Journal of the College Theology Society}

\author{
Published at Villanova University
}

Volume 38

Fall 2011

Number 2

ARTICLES

“All Will Be Well”: Julian of Norwich's

Counter-Apocalyptic Revelations Christopher Denny

On Presuppositions of Theological Ethics Norbert J. Rigali, SJ 211

The Hermeneutics of Vatican II: Reception, Authority, and Debate Over the Council's Interpretation Kristin Colberg 230 Edward Schillebeeckx's Creation Theology as a

Resource for Ecological Ethics Erica Olson-Bang

\section{EDITORIAL ESSAY}

Benedict XVI and Liberation Theology: Reason, Will, and History

\section{THEOLOGICAL ROUNDTABLE}

The Johnson Case and the Practice of Theology:

An Interim Report.

\section{BOOK REVIEWS}

Mary Katherine Birge, SSJ, Brian G. Henning,

Rodica M. M. Stoicoiu and Ryan Taylor,

Genesis Evolution and the Search for a

Reasoned Faith Michael Horace Barnes

Hilary Marlowe, Biblical Prophets and Contemporary

Environmental Ethics: Re-Reading Amos, Hosea, and First Isaiah Alice L. Laffey

Bernard Brandon Scott, The Trouble with

Resurrection: From Paul to the Fourth Gospel Pheme Perkins

Robert J. Karris, OFM, trans., Works of

St. Bonaventure: Commentary on the

Gospel of John Mary Margaret Pazdan, OP 
Le Groupe des Dombes, Catherine E. Clifford, trans.,

"One Teacher": Doctrinal Authority

in the Church

Michael A. Fahey, SJ 348

Stephen B. Bevans, An Introduction to Theology in a

Global Perspective John V. Kruse

Susan Abraham and Elena Procario-Foley, eds.,

Frontiers in Catholic Feminist Theology:

Shoulder to Shoulder Anne M. Clifford, CSJ 351

Francis X. Clooney, SJ, ed., The New Comparative

Theology: Interreligious Insights from the

Next Generation Paul F. Knitter

Terence Nichols, Death and Afterlife:

A Theological Introduction Peter C. Phan

Francis Schüssler Fiorenza and John P. Galvin, eds.,

Systematic Theology: Roman

Catholic Perspectives Gerald O’Collins, SJ 354

Joseph Ratzinger, The Ratzinger Reader:

Mapping a Theological Journey .Francis Schüssler Fiorenza 356

Pope Benedict XVI, Joseph Ratzinger in Communio,

Volume 1: The Unity of the Church Abraham B. Fisher

Patrick W. Carey, Avery Cardinal Dulles, SJ:

A Model Theologian 1918-2008 Phyllis Zagano 358

John Cornell, Newman's Unquiet Grave:

The Reluctant Saint Walter E. Conn 361

Jürgen Mettepenningen, Nouvelle Théologie-New

Theology: Inheritor of Modernism, Precursor of

Vatican II . David G. Schultenover, SJ

Oliva Blanchette, Maurice Blondel,

A Philosophical Life William L. Portier

George M. Marsden, A Short Life of

Jonathan Edwards William M. Shea 366

Avihu Zakai, Jonathan Edwards's Philosophy

of Nature: The Re-enchantment of the World

in the Age of Scientific Reasoning John J. Bombaro

Olga Lossky, Toward the Endless Day: The Life of Elisabeth Behr-Sigel Joseph A. Loya, OSA

Allen Brent, A Political History of Early Christianity ...... Vasilije Vranic Daniel Patte, ed., The Cambridge Dictionary of Christianity Gary Macy

Georges De Schrijver, SJ, The Political Ethics of

Jean-François Lyotard and Jacques Derrida

Margaret D. Kamitsuka, The Embrace of Eros:

Bodies, Desires, and Sexuality in Christianity David Gentry-Akin

John Wall, Ethics in Light of Childhood Christine Gudorf

John Sniegocki, Catholic Social Teaching

and Economic Globalization: The Quest for Alternatives. Thomas O'Brien 
Gabriel Moran, Believing in a Revealing God:

The Basis of the Christian Life

Francis Berna, OFM

Peter Tyler, St. John of the Cross David B. Perrin

Jerome P. Baggett, Sense of the Faithful: How

American Catholics Live Their Faith

BOOKS RECEIVED

INDEX

Copyright @ 2011 College Theology Society

Printed in the United States of America 


\section{HORIZONS}

\section{The Journal of the College Theology Society}

Horizons, The Journal of the College Theology Society is published biannually in Spring and Fall at Villanova University.

Yearly subscription: individual, $\$ 16.00$; institutional, $\$ 40.00$. Send remittance, payable to College Theology Society, P.O. Box 465, Hanover, PA 17331. Changes of address should also be sent to this address. Horizons is automatically received through membership in the College Theology Society.

Editorial and business correspondence, book reviews, advertising copy and orders for single issues (individual $\$ 8.00$, institutional $\$ 20.00$ ) should be sent to the editor at the Villanova University address (see below). Phone: 610.519.7302. E-mail: horizons@villanova.edu.

Articles are indexed in The Catholic Periodical and Literature Index; Arts and Humanities Citation Index; ATLA Religion Database; Index to Religious Periodical Literature and Religion Index One; New Testament Abstracts; Religious and Theological Abstracts; Social Science Citation Index. Book reviews are indexed in the Index to Book Reviews in Religion. Horizons is available in microform from University Microfilms, Inc., 300 North Zeeb Road, P.O. Box 1346, Ann Arbor, MI 48106-1346. It is also available online in full text to ATLAS (ATLASerials) subscribers.

\section{GUIDELINES FOR CONTRIBUTORS}

Manuscript submissions to the journal should be between 25 and 30 pages, not including notes. On rare occasions, the editors will give consideration to a lengthier submission of exceptional quality. The text and bibliographic documentation of the manuscript must conform to the Chicago Manual of Style (16th edition). We require that authors use endnotes rather than footnotes and that they double-space the entire manuscript.

Manuscripts must have a separate title page that includes the author's name, affiliation, e-mail address, postal address, an abstract of no more than 150 words, and an author vita of no more than 50 words. The author's name should appear nowhere else in the manuscript. All references to the author's work in the text or notes should be in the third person.

Our editorial office requires two copies: one digital and one hard copy. Send the digital copy of your manuscript to the journal's e-mail address (horizons@villanova.edu). The preferred digital format is Microsoft Word (.doc or .docx), but the journal can also accept WordPerfect (.wpd) or Rich Text (.rtf) if necessary. In a cover letter, the author should state that the manuscript will not be submitted to another journal until Horizons' evaluation is completed. Send the hard copy, along with the cover letter, to this address:

The Editor, Horizons, St. Mary's Hall, Villanova University, 800 Lancaster Avenue, Villanova, PA 19085

For further information about the journal's style guidelines, potential authors are strongly urged to visit the Horizons website (http://www.collegetheology.org/publica tions/horizons).

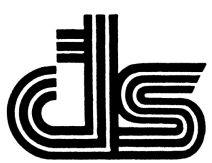

\section{COLLEGE THEOLOGY SOCIETY}

The College Theology Society is a professional organization of college and university professors of religion in the United States and Canada.

The purpose of the College Theology Society is to improve the quality of the teaching of religion: by stimulating and sharing scholarly research; by developing programs of theology and religious studies which meet student needs and interests; and by exploring, evaluating, and encouraging effective ways of teaching which are interdisciplinary and ecumenical.

Annual membership dues in the Society are $\$ 50.00$ (Full Professional or Associate), $\$ 50.00$ (Joint Professional for husband and wife), and \$25.00 (Graduate Student). Membership in the Society includes a subscription to Horizons. Contact Daniel T. Michaels, KEYPOPPY Christian Resources, 1726 West Cape Rock Drive, Cape Girardeau, MO 63701. Telephone: (573) 651-4199. E-mail: dmichaels@keypoppy.com 


\section{EDITOR}

Anthony J. Godzieba

Villanova University

\section{ASSISTANT EDITOR}

Elena G. Procario-Foley

Iona College

\section{ASSOCIATE EDITORS}

Lisa Sowle Cahill

Boston College

Denise Lardner Carmody

Santa Clara University

Bernard Cooke

College of the Holy Cross (Emeritus)

Lawrence S. Cunningham

University of Notre Dame

Charles E. Curran

Southern Methodist University

Margaret A. Farley

Yale Divinity School

Elisabeth Schüssler Fiorenza

Harvard Divinity School

Francis Schüssler Fiorenza

Harvard Divinity School
Mary Ann Hinsdale

Boston College

Elizabeth A. Johnson

Fordham University

Paul F. Knitter

Union Theological Seminary, NY

Pheme Perkins

Boston College

Sandra M. Schneiders, IHM Jesuit School of Theology at Berkeley

William M. Shea

College of the Holy Cross

Gerard S. Sloyan

Temple University (Emeritus)

David Tracy

University of Chicago

\section{BOOK REVIEW EDITORS}

Mary Doak

University of San Diego
Christopher Denny

St. John's University

BUSINESS EDITOR

Gerald S. Vigna

Alvernia College

\section{EDITORIAL ASSISTANT}

Irene C. Noble

EDITOR EMERITUS

Walter E. Conn

Villanova University 


\section{From the Editor}

Those of us who live in the northeastern part of the United States get to experience the poetic consonance of the four natural seasons with the richly evocative liturgical seasons of the year. As a gloriously colored early autumn has turned suddenly into a harbinger of a harsh winter and the end of the year, so too the Roman Catholic lectionary cycle familiarly prompts us to eschatological reflections and hope for the end time. Yet is it so familiar-or hopeful-this time around? As we raced toward the feast of Christ the King, parishes were scurrying to offer catechesis about the new English translation of the Roman Missal that were in use with the first Sunday of Advent. The familiar now becomes a bit foreign. Questions have been raised as to whether enough consultation with local priests and the faithful who populate the pews was done before the translation was authorized. Even a thirteen-year-old confirmation candidate asked, "Why are they doing this?" and direly predicted, "The kids won't learn these new prayers, they won't understand, and they'll stop coming to church. That's not good." We wonder what new forms of being church Advent might birth.

Consultation is also a question in the case of the "Statement" by the United States Conference on Catholic Bishops' Committee on Doctrine regarding Elizabeth Johnson's Quest for the Living God. As promised in the Spring 2011 edition, this issue features a study of some of the topics involved in the bishops' critique and Professor Johnson's June 1, 2011 response. Just as we were going to press, the bishops released their evaluation of Johnson's response, reaffirming their initial critique. We wonder what chilly winters await the theological community.

In some way, all of the articles capture a sense for that liminal space hovering between ending and beginning, darkness and light, eschatology and (re)creation. How do we envision a Christian eschatology that respects both human and divine freedom (Denny)? How do new categories in theology such as theological ethics (Rigali) or a theology of reception (Colberg) challenge us to articulate the cherished faith of the tradition in ever-changing contemporary circumstances? What resources in the tradition help us to confront the ecological crisis (Olson)? Our authors converge in different ways on the answer that the way from darkness into light is a God-centered, Christ-focused orientation.

In addition, the editorial essay and the roundtable consider questions about the use of language and history and how our methodological choices affect our presentation of the tradition and authority. The authors in this issue evince a great respect and love for the Christian faith as well as demonstrating and in some cases urging a hermeneutics of compassion (the phrase comes from the late Anne Carr) for each other's reflections on the mystery of faith.

As the nights lengthen and the snow falls steadily at this writing, we wonder about the future shape of theology and the relationships between laity and magisterium as we wait in hope with the Psalmist for that joy which comes in the morning (Ps 30).

The editorial staff offers a word of deep gratitude to Joann Wolski Conn and Eileen Flanagan, both of Neumann University, who have served Horizons faithfully as book review editors since 1982 and 2002, respectively, and whose terms ended with the Spring 2011 issue. We offer our thanks for your hard work at a demanding task and for your valuable contributions to the work of the Society. At the same time we give a hearty welcome to Christopher Denny (St. John's University) and Mary Doak (University of San Diego), whose terms as book review editors begin with this issue and whose contributions to the CTS are already well known.

Through endings and beginnnings, the efforts of the readers and contributors to Horizons, theologians working on behalf of church and world, continue. Horizons is proud to support these efforts. 